\title{
Geodynamic condition of formation of favorable structural positions for ore-grade gold placement in auminzatau-beltau ore area (the central kyzyl kum, western uzbekistan)
}

\author{
Geodinamični pogoji nastanka struktur, ugodnih za odlaganje \\ zlata rudnih vsebnosti v auminzatau-beltauskem rudnem območju \\ (osrednji kyzyl kum, zahodni uzbekistan)
}

\section{Bobir Omonovich Janibekov ${ }^{1, *}$, Turapov M.K.}

${ }^{1}$ Institute of Mineral Resources, State Committee of the Republic of Uzbekistan on Geology and Mineral Resources, Tashkent *jonibekovbobur@mail.ru

\begin{abstract}
Work is directed on studying of a geodynamic condition under which the structural positions controlling process of endogenous ore formation were formed. It is shown that explosive region tectonics under the influence of regional tectonic efforts formed structural elements (positions) which controlled formation of gold deposits. It is recognized that structural positions are defined by variety of systems of disjunctive dislocation and their relationship among themselves. Formation of favorable positions depends as well on morphology of ore controlling structures, on degree of their tectonic activity and spatial situation in relation to the direction of tectonic (geodynamic) efforts.
\end{abstract}

Key words: structural position, ore-grade gold, faults, block structure, gold occurrences, geodynamic conditions, activity.

\section{Povzetek}

Delo poroča o raziskavi geodinamičnih pogojev nastajanja struktur, ki so bile kontrolni dejavnik pri odlaganju endogenih rud. Prikazane so okoliščine, v katerih so se oblikovali pod vplivom regionalnih tektonskih premikov strukturni elementi, ki so kontrolirali odlaganje nahajališč zlata. Ugotavljajo, da so ti elementi opredeljeni z različnimi vrstami prelomnih dislokacij in njihovega medsebojnega učinkovanja. Nastajanje ugodnih strukturnih elementov je odvisno tudi od oblikovanosti kontrolnih struktur, stopnje njihove tektonske aktivnosti in prostorskega razporeda glede na usmeritve tektonskih (geodinamičnih) sil.

Ključne besede: strukturna lega, zlato rudnih vsebnosti, prelomi, strukturni bloki, pojavi zlata, geodinamični pogoji, tektonska dejavnost. 


\section{Introduction}

In a geological structure of the Western Uzbekistan various rock types participate in various combinations which are characterized by a certain structure and petrographic properties that defined variety of tectonic elements which were the main reason for formation of various structural and geological types of ore fields and deposits and their geological and structural positions [1].

Korolev V.A. [2] notes that at classification of geological and structural types of ore fields and deposits many researchers do not draw a clear boundary between structural type and a structural position. Quite often structural type of ore objects is substituted for their structural position and vice versa.

As Thomson I.N. specifies [3] one of actual problems in ore geology is clarification of conditions of ore objects spatial placement in certain ore-bearing areas. The solution of this problem has extremely important value at design with carrying out prognostic and exploration works. Having defined a structural and geological position of known ore deposits, it is possible to allocate the prospective areas where there is a probability of detection of new industrial facilities $[1,4,5]$.

For gold deposits of Central Kyzyl Kum their consistent patterns of formation are so far determined [6-8] factors of control of an ore grade mineralization as regional scale [9], and local scale are defined [10,11]. Geochemical and mineralogical features of ores, and also geophysical parameters of the areas of ore grade mineralization occurrences are revealed. However the question of their position in structural elements of the region remains open. In this regard our researches were directed on definition of structural position of gold deposits and ore occurrence of the Auminzatau-Beltau ore area located in the southeast Central Kyzyl Kum.

\section{Materials and methods}

Works are the cornerstone geological materials of State Committee of the Republic of Uzbekistan on Geology and Mineral Resources of the Republic of Uzbekistan, and also results field re- search in the Auminzatau-Beltau ore area. The technique of researches consists in a complexation: methods of the geological and structural analysis of conditions of formation and placement of an endogenous ore grade mineralization; operations research on studying tectonic stress and deformation of the areas of endogenous hydrothermal ore-grade mineralization occurrences; a method of reconstruction of a geodynamic situation in ore fields and deposits in ore formation processes.

\section{Results of research}

Many researchers in due time were engaged in studying of geological and structural conditions of gold fields and deposits formation and placements of ore-grade mineralization in them. Result of their researches was determination of geological regularities of formation of gold ore deposits with allocation of the concrete geological reasons controlling their formation. Thus the special attention was paid to structural factors. But despite significant progress in detection of gold deposits formation regularities in the region for many of them the different interpretation in allocation of ore controlling factors is characteristic, and the question of their structural positions remains unresolved.

According to Korolev V.A. [2] the position of ore object is area of geological structure within which joint influence of several structural elements providing intake of endogenous solution was shown. It is necessary to range in their number: fault bend area; areas of their crossings and intersecting and junction; zones of fault parting; zones of correlative faults convergence; areas of complication of folds with faulting, etc. All these elements define an object position in geological space and where there is a concentration of chemical elements, being formed in the form of ore block.

Interrelation of structural elements of crust with the ore-bearing solutions arriving from depths we will consider on the example of gold objects of the Auminzatau-Beltau ore area.

In Beltau occurrences of gold were formed under the influence of the wide range of structural elements. The analysis of a position allowed to divide them into seven groups: zone of north- 


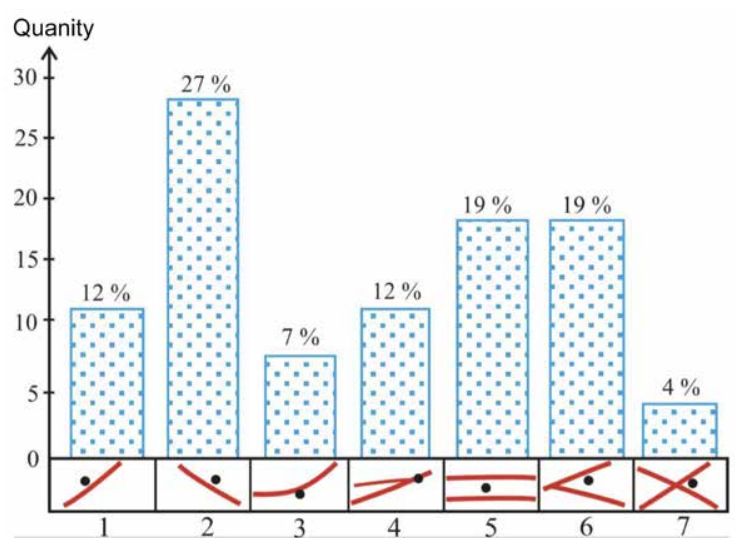

Figure 1: Allocation of gold ore occurrences of Auminzatau on structural positions. Structural positions: 1-zone of a northeast fault; 2-zone of a northwest fault; 3-zone of curvature of fault; 4- zone of branching of faults; 5 -zone of subparallel faults; 6 - zone of wedge-shaped structures; 7-zone of crossings of daults.

east and northwest breaks; areas of curvatures and crossings of faults; shear zone; the areas between parallel faults and a zone of wedgeshaped structures (Figure 1 and 2). In these seven structural positions almost all gold occurrences of Beltau were formed. Wide range of structural positions indicates activity of the tectonic condition preceding ore formation processes which caused such variety of structural elements and their combinations. Amount of the formed gold objects in these positions also unevenly. In zones of northeast faults one object was formed. The same situation is characteristic for zones of northwest faults as well. Two and two objects are defined in the positions connected with of curvatures of faults areas in zones of their crossings and in share zones (branching) of faults. In the areas between subparallel faults three gold objects are noted. The most large number of gold occurrences is connected with wedge-shaped structures. About $40 \%$ of gold objects were formed in these structures.

Allocation of gold occurrences in Auminzatau on structural positions is also uneven. The minimum quantity of gold occurrences is noted in a zone of crossing of faults. With northeast faults and their branches spatially it is connected six (about 23\%) occurrences. Five and five (19\%) occurrences are defined in zones between parallel faults and wedge-shaped structures. The maximum number $(27 \%)$ of gold occurrences is connected with northwest faults.

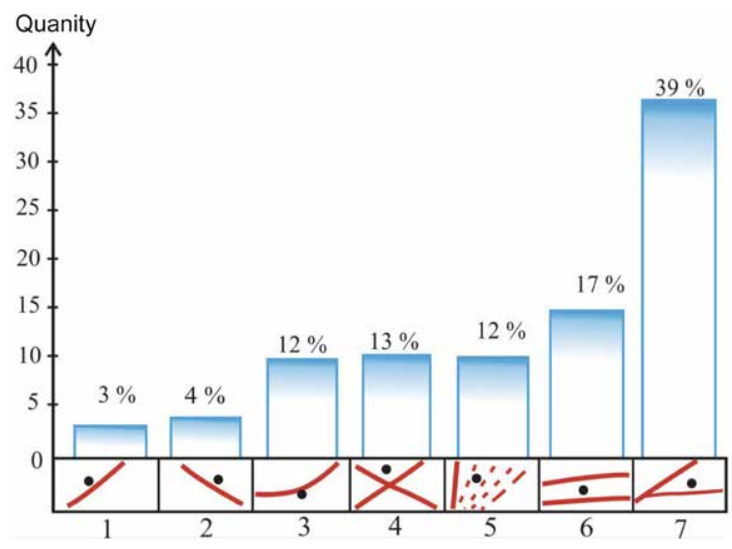

Figure 2: Allocation of gold ore occurrences of Beltau on structural positions. Structural positions: 1 zone of a northeast fault; 2 zone of a northwest fault; 3 zone of a curvature of fault; 4 zone of crossings of faults; 5 share zone; 6 zone of subparallel faults; 7 zone of wedge-shaped structure.

Thus, considering and analyzing placement in geological space of gold occurrences in Auminzatau and Beltau, similarity and distinction in placement of gold objects in structural positions is revealed.

There is a question - why the same structural elements and their combinations unevenly influence the course of processes of ore formation in the Auminzatau-Beltausky ore area? So, for example, northeast and northwest faults of Beltau define a position on one gold occurrence whereas in Auminzatau they respectively influence formation of three and six gold occurrences. For search of the answer to a question it was necessary to analyse ore bearing geological data of an area, and also to consider a geodynamic situation of the period of ore formation. The analysis of structural positions of gold occurrences in Beltau's mountains revealed one feature - almost in all structural positions ore controlling northeast faults are directly involved. Formation of wedge-shaped structures, formation of zones of subparallel faults, crossings and junction of faults, a curvature of faults, zones of a branching is directly connected with northeast faults.

Reconstruction of a geodynamic condition and the mechanism of northeast faults formation allowed to conclude that impact of regional horizontal efforts of compression on all territory of Central Kyzyl Kum happened ambiguously. Reason was existence of regional northwest systems of ruptural structures and a block struc- 
ture of the region. Distinction in parameters and morphology of tectonic blocks and their spatial situation in Central area of Kyzyl Kum in a complex with explosive tectonics predetermined extent of influence of regional horizontal efforts of compression to each of them. Thus efforts of compression can be weakened or, on the contrary, are strengthened. Everything depends on geodynamics of ruptural structures. At activity of faults (in the form of shift fault) disperses on horizontal movement on faults. In the absence of any vertically horizontal movements on a fault when there is a cover of its vacuity, impact of compression on the block that provokes them to shift amplifies, changing its internal geodynamic situation.

Studying of tectonics and geological structure of mountains of Beltau and Auminzatau allowed to reveal essential distinction in their structural and tectonic structure that points to distinction in their geodynamic conditions. The distinction reason in geodynamics should be looked for in their positions in regional tectonic structures. Analyzing all data on region tectonics stated in works of Akhmedzhanov M.A., Bukharin A.K., Rezvaya P.D., etc. came to a conclusion that geodynamic conditions and Beltau and Auminzatau's structural and tectonic framework are caused by their block structure.

Block structure provided distinction of their structural elements and defined what of them will promote formation and placement of a gold ore mineralization. Besides, the morphology of blocks is one of the reasons of change of a geodynamic condition formation in each block, and also defines the direction of their movements. Distinction in structural positions of gold occurrences of Beltau and Auminzatau where main structures are, respectively, northeast and northwest ruptural structures allow to consider Beltau and Auminzatau as two certain areas that have common features in geological structure, but differ on tectonics and geodynamics.

\section{Results and discussions}

1. In the Auminzatau-Beltau ore area seven reference structural positions which controlled formation of all known gold occurrences are allocated. However allocation of deposits and ore occurence in them extremely irregularly.

2. After consideration and the analysis of structural position and gold occurrences of Auminzatau and Beltau separately, their similarity and sharp distinction in gold objects placements in them is revealed. If in Auminzatau about $40 \%$ of gold objects were formed in the structural positions connected with northeast and northwest faults, in Beltau approximately as much of objects it is revealed in the wedge-shaped structures formed by interface of submeridional and northeast cataclasis.

3. A variety of structural positions is caused by variety of ruptural structures and a small block structure of the area that in a complex with the geological environment promoted frequent change of the geodynamic condition. The geodynamic condidtion is a key factor in activity of ore controlling structures which leads to formation of structural positions for favorable placement of ore grade mineralization.

\section{References}

[1] Akbarov, H.A. (2006): Geological and structural conditions of placement and forecasting of an ore grade mineralization on polymetallic ore fields of Tien Shan. Tashkent: Tashkent State Technical university named after Abu Raykhon Beruni, 259-281.

[2] Korolev, V.A. (1983): Structural types of ore fields and deposits of Central Asia. Moscow, "Subsoil", 216 p.

[3] Thomson, I.N., Favorsky, M.A. (1968). Ore controlling structures and principles of local forecasting of an endogenous ore mineralization. Soviet geology, 10, pp. 6-20.

[4] Akbarov, H.A. (2004): Geological and structural positions of ore fields and deposits of Tien Shan. Problems of studying and systematization. Geology and mineral resources, 2, pp. 3-10.

[5] Umarkhodzhayev, M.U., Akbarov, H.A., Turapov, M.K. (2003): Methodology of mineral deposits forecasting. Tashkent: Tashkent State Technical university named after Abu Raykhon Beruni, 385 p.

[6] Hamrabayev, I.H. (1969): Petrological and geochemical criteria of a ore-bearing magmatic complexes (on the example of Uzbekistan). Tashkent: "Fan". 
[7] Rakhmatullayev, H.R. (1972): About Caledonian and Hercynian eras of a gold mineralization in the Western Uzbekistan (on the example of an Kokpatas ore field). Results of petrometallic researches, "Fan", pp. 154-170.

[8] Rakhmatullayev, H.R. (1992): Ore formations and deep circles of an ore mineralization of a late-orogenic stage of development of Hercynides, "Fan", 240 p.

[9] Hamrabayev, I.H., Horvat, V.A., etc. (1973): To character of a tungsten mineralization on a Charmitan gold deposit in the Western Uzbekistan. Uzb. geol. Zhurn, 1, pp. 3-11.

[10] Golovanov, I.M. (2001): Ore deposits of Uzbekistan. Tashkent: IMR, $580 \mathrm{p}$.

[11] Paramanov, Yu.I. (2007): Factors of localization of gold-bearing objects in the Southern Tien Shan on the example of the Kokpatas trend in of Bukantau. Modern problems of geology and development of mineral resources of the Republic of Uzbekistan, pp. 123-129. 
